\title{
Faktor-Faktor Yang Mempengaruhi Peran DPRD Dalam Pengawasan Keuangan Daerah
}

\author{
Memed Ronsumbre ${ }^{1}$, Simson Werimon ${ }^{2}$, Hustianto Sudarwadi ${ }^{2}$ \\ ${ }^{1}$ Alumni Program Studi Akuntansi, Universitas Papua \\ ${ }^{2}$ Program Studi Akuntansi, Universitas Papua
}

Received: Januari 2019; Accepted: Februari 2019; Published: Maret 2019

\begin{abstract}
Abstrak
Penelitian ini bertujuan untuk menguji pengaruh personal background, political background dan pengetahuan dewan tentang anggaran terhadap peran anggota DPRD dalam pengawasan keuangan daerah. Penelitian ini dilatar belakangi oleh fakta-fakta bahwa latar belakang individu akan berpengaruh terhadap perilaku individu dalam peran dan aktivitas politik. Variabel dependen penelitian ini adalah peran anggota DPRD dalam pengawasan keuangan daerah. Variabel independennya adalah personal background, political background dan pengetahuan dewan tentang anggaran. Data penelitian ini berupa data primer dari 43 responden yang merupakan anggota DPRD Provinsi Papua Barat. Pengujian hipotesis menggunakan regresi linear berganda. Hasil penelitian ini mengindikasikan bahwa pertama, personal background berpengaruh terhadap peran anggota DPRD dalam pengawasan keuangan daerah. Kedua, political background tidak berpengaruh terhadap peran anggota DPRD dalam pengawasan keuangan daerah. Ketiga, pengetahuan dewan tentang anggaran berpengaruh positif terhadap peran anggota DPRD dalam pengawasan keuangan daerah.
\end{abstract}

Kata kunci: personal background, political background, pengetahuan tentang anggaran, peran anggota DPRD, pengawasan keuangan daerah minimum

\begin{abstract}
This study aims to examine the influence of personal background, political background and knowledge of council about budget towards the role members of DPRD on financial region supervision. This research is motivated by the fact individual backgroundwill effect to individual behavior for their role and on political activity. Dependent variable in this research is the role of members of DPRD on financial region supervision. Independent variables are personal background, political background and knowledge of council about budget. The data used is primary data that taken from 43 respondents who are members of DPRD at West Papua Province. Hipothesis examinations in this study are tested using Multiple Linear Regression. The results indicated that, first, there is a positive influence of personal background toward the role members of DPRD on financial region supervision. Second, political background haven "t effect towards the role members of DPRD on financial region supervision. Third, knowledge of council about budget affect towards the role members of DPRD on financial region supervision.
\end{abstract}

Keywords: personal background, political background, knowledge about budget, the role members of DPRD, financial region supervision

How to Cite: Ronsumbre, M., Werimon, S., Sudarwadi, H. (2019). Faktor-faktor Yang Mempengaruhi Peran DPRD Dalam Pengawasan Keuangan Daerah. JFRES: Journal of Fiscal and Regional Economy Studies, 2 (1), $58-68$.

Corresponding author:

E-mail: hustianto@gmail.com 


\section{PENDAHULUAN}

Sesuai dengan Undang-Undang Dasar (UUD) 1945 Pemerintah orde baru dinilai tidak mampu mewujudkan kehidupan masyarakat yang adil dan makmur. Dimana pembangunan Indonesia berorientasi pada pertumbuhan ekonomi sehingga menyebabkan ketidakadilan dan kesenjangan sosial. Bahkan, antara pusat dan daerah terjadi kesenjangan pembangunan karena sebagian besar kekayaan daerah disedot kepusat. Hal ini menyebabkan pelaksanaan desentralisasi untuk mewujudkan otonomi daerah sebagai salah satu tuntutan daerah masyarakat dalam pelaksanaan otonomi.

Sejak dikeluarkan peraturan tentang otonomi daerah yaitu UU Nomor 9 Tahun 2015 tentang Pemerintah Daerah dan UU No 33 Tahun 2004 tentang perimbangan keuangan antara pemerintah pusat dan daerah, maka kekuasaan atau tanggungjawab yang dibebankan kepada pemerintah daerah untuk mengelola daerahnya secara maksimal menjadi lebih besar. Hal ini ditunjukan supaya distribusi dan pemanfaatan sumber daya alam dapat merata dan terciptanya keseimbangan keuangan antara pemerintah pusat dan daerah. Dengan otonomi daerah, setiap Provinsi mendapatkan Anggaran Pendapatan Belanja Daerah (APBD) masing-masing untuk mengelola dana tersebut sebagai sarana yang akan digunakan untuk memenuhi kebutuhan daerahnya. Namun, tidak jarang dalam pengunaannya terjadi penyalagunaan serta manipulasi yang dilakukan oleh oknum pemerintah daerah. Untuk mewujudkan otonomi daerah dan desentralisasi yang luas, nyata dan bertanggungjawab diperlukan manajemen keuangan daerah yang mampu mengontrol kebijakan keuangan daerah secara ekonomis, efisien, efektif, transparan dan akuntabel (Amelia, 2013).

Undang-Undang Nomor 9 Tahun 2015 tentang Pemerintah Daerah dan 33 Tahun 2004 tentang perimbangan keuangan daerah, telah merubah pertanggungjawaban pemerintah daerah dari pertanggungjawaban vertikal ke horizontal. Sehingga akuntabilitas dalam pengelolaan keuangan daerah menjadi lebih jelas. Berlakunya UU tentang otonomi daerah memberikan dampak positif bagi kedudukan, hak dan posisi DPRD untuk melaksanakan fungsinya dengan aktif yaitu menampung dan menyampaikan aspirasi masyarakat. Dengan adanya otonomi daerah ini pemerintah dituntut untuk menciptakan good governance yaitu dengan mengutamakan akuntabilitas dan transparansi serta didukung dengan pengawasan keuangan daerah yang dapat di pertanggungjawabkan dengan baik.

Berdasarkan Peraturan Pemerintah Nomor 58 Tahun 2005 tentang pengelolaan keuangan daerah menjelaskan bahwa: (1) Pengawasan atas keuangan daerah dilakukan oleh dewan, (2) Serta adanya pemeriksaan pengelolaan keuangan daerah oleh eksternal BPK. Peraturan Pemerintah Nomor 12 Tahun 2018 tentang pedoman penyusunan peraturan tata tertib menyebutkan lembaga legislatif mempunyai tiga fungsi yaitu: (1) Fungsi legislasi (pembuatan perundang-undangan), (2) Fungsi anggaran (menyusun anggaran), (3) Fungsi pengawasan (mengawasi kinerja eksekutif).

Berdasarkan penjelasan diatas maka aspek penting dalam pelaksanaan otonomi daerah dan desentralisasi adalah masalah keuangan dan anggaran APBD. Oleh karena itu, diperlukan peran DPRD yang sangat besar untuk mengontrol kebijakan keuangan daerah APBD yang ekonomis, efisien, efektif, transparan dan akuntabel (Nisa, 2014). Namun pada kenyataannya masih banyak terjadi kasus penyalahgunaan yang terjadi diberbagai daerah. Salah satunya di Provinsi Papua Barat. Dimana kasus penyalahgunaan dana APBD Kabupaten Manokwari Tahun 2008 sampai 2010 sebesar tujuh puluh milyar. Selain itu kasus korupsi anggaran APBD Papua Barat tahun 2011-2012 yang merugikan Negara tujuh puluh delapan milyar dan menyeret mantan sekda Papua Barat. Permasalahan tersebut dapat timbul karena kurangnya peran DPRD dalam pengawasan anggaran APBD. Lemahnya fungsi pengawasan legislatif merupakan faktor yang mempengaruh kinerja legislatif terhadap eksekutif. Pengawasan keuangan daerah APBD yang dilakukan oleh dewan dipengaruhi oleh sistem dan individu secara pribadi, (Winarna, $d k k$ 2007). Secara akrual kegiatan politik dilakukan oleh individu, sedangkan perilaku lembaga politik padadasarnya berpedoman pada perilaku dengan pola tertentu. Oleh karena itu, untuk menjelaskan suatu perilaku suatu lembaga dalam hal ini DPRD yang perlu ditelaah bukan lembaganya, melainkan latar belakang individu yang menjalankan dan mengendalikan jalannya lembaga tersebut. Sehingga perlu ditelaah lebih dalam variabel-variabel yang mempengaruhi peran DPRD dalam pengawasan keuangan daerah. Dalam penelitian ini variabel yang ditelaah antara lain: personal background, 
political background, dan pengetahuan dewan tentang anggaran.

Personal background merupakan latar belakang diri yang melekat pada seorang individu. Latar belakang inimeliputi aspek nama, jenis kelamin, usia, agama, latar belakang pendidikan dan sebagainya. Personal background berkaitan erat dengan kualitas sumber daya manusia. Sumber daya manusia merupakan pilar utama penyangga sekaligus pengerak roda organisasi dalam usaha mewujudkan elemen organisasi yang sangat penting. Oleh karena itu, sumber daya manusia ini harus dikelola sebaik mungkin agar mampu memberikan kontribusi secara optimal dalam upaya pencapaian tujuan organisasi (Amelia, 2011).

Menurut Handoyo (2011), strata pendidikan dan latar belakang pekerjaan berpengaruh signifikan terhadap pengawasan keuangan daerah. Sedangkan menurut Amelia (2013), variabel personal background meliputi jenis kelamin, usia, tingkat pendidikan, bidang pendidikan dan latar belakang pekerjaan menunjukan tidak memiliki pengaruh yang signifikan terhadap pengawasan keuangan daerah. Dalam penelitian ini peneliti ingin mencoba menguji kembali hasil penelitian yang dilakukan oleh Amelia (2013), dimana variabel idenpendennya adalah strata pendidikan, pengalaman organisasi, dan lama kerja dipemerintah. Variabel ini mengadopsi dari penelitian (Amelia, 2013).

Political background merupakan latar belakang yang menyangkut semua tentang dunia politik. Political background dalam hal ini meliputi pengalaman DPRD selama berjabat di Partai Politik. Setiap anggota DPRD diwajibkan menjalankan tugas dan tanggungjawab sesuai dengan aturan yang ditetapkan oleh masingmasing komisi, hal ini yang menyebabkan terjadinya perbedaan. Oleh karena itu, setiap anggota DPRD harus mempunyai latar belakang politik yang baik dalam menjalankan tugas dan wewenangnya masing-masing (Amelia, 2013). Seorang anggota dewan harus mempunyai latar belakang politik yang baik dalam menjalankan tugasnya sebagai anggota dewan. Ada beberapa faktor yang mempengaruhi sikap, perilaku, dan peran legislatif. Yaitu, institusi politik, partai politik, karakteristik personal, pengalaman politik, dan sifat memilih (Winarna, $d k k$ 2007). Hasil yang dilakukan oleh Winarna, $d k k$ (2007), variabel political background tidak berpengaruh secara signifikan terhadap pengawasan keuangan daerah. Sedangkan menurut Kartikasari (2012), menunjukkan bahwa variabel political background mempunyai pengaruh positif dan signifikan terhadap pengawasan keuangan daerah.

Pengetahuan anggota DPRD tentang anggaran dapat diartikan sebagai pengetahuan dewan terhadap mekanisme penyusunan anggaran mulai dari tahap perencanaan sampai dalam tahap pertanggungjawaban serta pengetahuan tentang undang-undang yang mengatur pengelolaan keuangan daerah APBD. Penelitian yang dilakukan oleh Amelia (2013), menunjukan bahwa pengetahuan dewan tentang anggaran berpengaruh positif dan signifikan terhadap pengawasan keuangan daerah. Sedangkan hasil penelitian Nisa (2016), menunjukan bahwa pengetahuan dewan tentang anggaran berpengaruh negatif dan signifikan terhadap pengawasan keuangan daerah.

Berdasarkan uraian diatas, tujuan penelitian ini adalah:

1. Untuk mengetahui pengaruh personal background terhadap pengawasan keuangan daerah.

2. Untuk mengetahui pengaruh political background terhadap pengawasan keuangan daerah.

3. Untuk mengetahui pengaruh pengetahuan anggota Dewan terhadap pengawasan keuangan daerah.

\section{METODE PENELITIAN}

Tempat penelitian ini dilaksanakan di DPRD Provinsi Papua Barat Manokwari. Jenis penelitian yang digunakan adalah penelitian deskriptif kuantitatif. Menurut (Suliyanto, 2006), riset kuantitatif adalah riset yang didasarkan pada data kuantitatif dimana data kuantitatif adalah data yang berbentuk angka dan bilangan. Jenis data yang digunakan dalam penelitian ini adalah data primer. Data primer adalah sumber data yang langsung memberikan data kepada pengumpul data (Sugiyono, 2012), sumber data primer dalam penelitian ini adalah kuesioner yang diadopsi dari penelitian (Amelia, 2013) dengan mengunakan alat bantu SPSS.

Populasi adalah wilayah yang terdiri atas subjek/objek yang merupakan kuantitas dan karakteristik tertentu yang diterapkan oleh peneliti untuk dipelajari dan kemudian ditarik kesimpulan (Sugiyono, 2012). Populasi dalam penelitian ini adalah seluruh anggota DPRD Provinsi Papua Barat periode 2014-2019 yang berjumlah 56 orang. Dari populasi tersebut, maka jumlah sampel yang diperoleh dengan 
menggunakan rumus Slovin sebanyak 49 anggota DPRD Provinsi Papua Barat.

Personal background adalah latar belakang yang berkaitan dengan sumber daya manusia. Personal background dalam penelitian ini adalah pendapat anggota dewan mengenai latar belakang yang dapat mendukung pengawasan keuangan daerah. Latar belakang tersebut merupakan tingkat pendidikan, latar belakang pendidikan, pengalaman organisasi, dan lain lain. Kuesioner yang diajukan terdiri dari 8 pertanyaan yang bersumber dari penelitian (Amelia, 2013). Dari kuesioner yang diajukan diharapkan mampu menggambarkan pengaruh personal background terhadap kinerja DPRD sebagai pengawaskeuangan daerah.

Political background merupakan latar belakang dari pengalaman seseorang yamg telah berkecimpung dalam dunia politik variabel ini meliputi beberapa dimensi, yaitu: pengalaman politik, pengalaman di DPRD, latar belakang partai politik, asal komisi, jabatan dipartai politik, dan jumlah partai politik yang pernah diikuti. Kuesioner yang diajukan terdiri dari 8 pertanyaan yang bersumber dari penelitian (Amelia, 2013).

Pengetahuan dewan tentang anggaran dapat diartikan sebagai pengetahuan dewan terhadap mekanisme anggaran mulai dari proses penyusunan anggaran sampai pada tahap pertanggungjawaban (Amelia, 2013). Kuesioner yang diajukan oleh peneliti terdiri dari 9 pertanyaan yang diadopsi dari (Amelia, 2013).

Pengawasan secara umum dapat diartikan sebagai proses kegiatan yang bertujuan untuk menjamin suatu kegiatan tersebut berjalan sesuai dengan rencana dan tujuan yang telah disepakati (Dewi, 2011). Pengawasan dalam penelitian ini dilakukan oleh anggota DPRD mulai dari tahap perencanaan, penyusunan, hingga pertanggungjawaban APBD. Anggaran Pendapatan Belanja Daerah (APBD) merupakan rencana keuangan tahunan pemerintah daerah yang disetujui oleh DPRD dan ditetapkan oleh peraturan daerah.

Seluruh variabel diukur menggunakan skala likert. Skala likert merupakan metode pengukuran yang berisi beberapa alternatif kategori pendapat yang memungkinkan bagi responden untuk memberikan alternatif penilaian (Indriantoro, dkk, 1999) dalam (Winarna, 2007) yang sesuai dengan sikap dan tindakan yang dilakukan atas pernyataan yang diajukan. Kuesioner yang diajukan oleh peneliti terdiri dari 9 pertanyaan yang diadopsi dari (Amelia,
2013). Pengukuran variabel dilakukan dengan skala 1-5, yaitu: $1=$ Sangat Tidak Setuju (STS), 2= Tidak Setuju (TS), 3= Setuju (S), 4= Tidak Tahu (TT), 5= Sangat Setuju (SS).

Metode pengumpulan data yang dilakukan dalam penelitian ini adalah survei dan observasi yang dilakukan langsung dengan membagikan kuesioner dilingkungan DPRD Provinsi Papua Barat. Kuesioner tersebut berisi tentang pertanyaan tertulis kepada responden. Metode penyebaran kuesioner dengan menggunakan Personally Administrated Questionaires, yaitu penggunaan kuesioner yang disampaikan dan dikumpulkanoleh peneliti dengan menemui responten secara langsung. Sehingga peneliti dapat memberikan penjelasan seperlunya kepada responden mengenai hal-hal yang belum dimengerti oleh responden (Dewi, 2011).

Personal background merupakan latar belakang diri yang melekat pada seseorang. Kaitannya dengan anggota DPRD dalam mengawasi keuangan daerah, anggota DPRD harus bertindak sesuai peran yang sudah dijalani. Personal background meliputi jenis kelamin, usia, tingkat pendidikan, pengalaman pekerjaan, dan pengalaman organisasi. Dalam penelitian ini personal background anggota DPRD dari tahun 2014-2019. Hal ini berlaku juga bagi anggota dewan dalam pengawasan keuangan daerah. Apabila anggota dewan lulusan sarjana dan jenjang pendidikan yang rendah akan memiliki perilaku yang berbeda. Seperti halnya pengetahuan tentang pemerintah keuangan daerah dan keseluruhan tentang pengawasan keuangan daerah. Dari penjelasan tersebut dapat disimpulkan bahwa strata pendidikan seorang anggota dewan akan mempengaruhi peran anggota DPRD dalam pengawasan keuangan daerah.

Pelatihan dan pendidikan sangat penting untuk diperhatikan karena pendidikan dan pelatihan yang dimiliki seseorang sangat berpengaruh terhadap pola pikir, tindakan dan peran seseorang dalam suatu masyarakat atau organisasi. Teori keagenan menjelaskan mengenai adanya hubungan antara principal dan agent, kaitannya dengan pemerintah daerah atau eksekutif merupakan agent dan DPRD sebagai principal. Pengawasan keuangan daerah yang dilakukan oleh dewan dipengaruhi oleh sistem individu secara pribadi (Winarna, 2007).

Beberapa peneliti sebelumnya yang menguji personal background dengan kinerja anggota DPRD dalam pengawasan keuangan daerah APBD, seperti Dewi (2011) dan Nisa (2016), 
menyimpulkan bahwa personal background berpengaruh positif terhadap pengawasan keuangan daerah. Berdasarkan uraian diatas maka hipotesis yang diajukan sebagai berikut:

H1: Personal Background berpengaruh terhadap pengawasan keuangan daerah.

Political background merupakan latar belakang dari pengalaman seseorang yang berkecimpung dalam dunia politik. Dalam penelitian ini adalah pengalaman anggota dewan dalam dunia politik. Pengalaman merupakan bekal yang baik dan akan mempengaruhi perilaku seseorang dalam suatu organisasi. Seseorang yang sudah mempunyai pengalaman dalam dunia politik akan mempunyai pengalaman dan tahu bagaimana cara melaksanakan tugas dan tangung jawab sebagai anggota dewan terutama dalam pengawasan keuangan daerah.

Dalam menjalankan tugas dan tanggung jawabnya sebagai anggota dewan diharuskan mengikuti aturan kerja yang ditetapkan sesuai dengan bidang masing-masing, disinilah latar belakang politik terkadang menyebabkan perbedaan sudut pandang bahkan terjadinya perselisihan. Menurut Dewi (2011), terdapat beberapa faktor yang mempengaruhi sikap, perilaku, dan peran legislatif. Yaitu: institusi politik, partai politik, karakteristik personal dan pengalaman politik. Semakin seorang anggota DPRD mempunyai pengalaman yang banyak dalam dunia politik maka semakin maka semakin berkualitas pengetahuan dalam pengawasan keuangan daerah.

Dalam penelitian yang dilakukan oleh Kartikasari (2012), menyimpulkan bahwa Political background berpengaruh terhadap peran anggota DPRD dalam pengawasan keuangan daerah. Berdasarkan uraian diatas maka hipotesis yang diajukan sebagai berikut:

$\mathrm{H} 2$ : Political background berpengaruh terhadap pengawasan keuangan daerah.

Pengetahuan anggota DPRD tentang anggaran dapat diartikan sebagai pengetahuan dewan terhadap mekanisme penyusunan anggaran mulai dari tahap perencanaan sampai pada tahap pertanggungjawaban serta pengetahuan tentang peraturan perundangan yang mengatur tentang pengelolaan keuangan daerah (Amelia, 2013).

Berdasarkan pendekatan teori peran bahwa seorang individu dapat berperilaku sesuai peran yang dijalani. Untuk menjalankan tugasnya dalam mengawasi keuangan daerah yang baik anggota dewan harus mengetahui aturan-aturan dalam undang-undang. Pengetahuan dewan tentang anggaran erat kaitannya dengan kinerja sebagai pengawas keuangan. Semakin luas pemahaman tentang peraturan undang-undang maka semakin baik dalam mengontrol jalannya APBD dan mengurangi terjadinya kecurangan.

Dalam penelitian sebelumnya yang menguji pengetahuan dewan tentang anggaran Amelia (2013), menyimpulkan bahwa pengetahuan anggota dewan tentang anggaran berpengaruh positif terhadap peran DPRD dalam pengawasan keuagan daerah.

H3: Pengetahuan dewan tentang anggaran berpengaruh terhadap pengawasan keuangan daerah.

Uji validitas yang digunakan menggunakan teknik analisis bivariate correlation dengan syarat yang digunakan untuk menyatakan item pernyataan valid. Kuesioner yang digunakan dikatakan valid apabila nilai signifikansi $<0.05$ (Ghozali, 2007). Uji reliabilitas dilakukan untuk mengetahui apakah jawaban responden terhadap pernyataan-pernyataan yang diajukan memiliki tingkat kestabilan yang tinggi dari waktu kewaktu atau tidak. Dengan kata lain, kuesioner dikatakan reliable atau handal jika jawaban seseorang terhadap pernyataan adalah konsisten atau stabil. Suatu variabel dikatakan reliable atau handal apabila mempunyai nilai cronbach's Alpha $>0,60$ (Ghozali, 2007).

Pengujian asumsi klasik yang digunakan adalah uji normalitas, uji multikolinearitas, dan uji heteroskedastisitas. Uji normalitas dilakukan untuk mengetahui apakah dalam model regresi, variabel-variabel memiliki distribusi normal. Data yang terdistribusi normal akan memperkecil kemungkinan terjadinya bisa. Untuk menguji apakah data berdistribusi normal atau tidak dilakukan uji statistik Kolmogorov Smirnov Test. Residul terdistribusi normal jika nilai signifikansi $>0.05$ (Ghozali 2007).

Uji multikolonearitas bertujuan untuk menguji apakah model regresi ditemukan adanya korelasi antar variabel independen, maka uji jenis ini hanya diperuntukan untuk penelitian yang memiliki variabel independen lebih dari satu. Multikolonearitas dapat dilihat dengan menganalisis nilai VIF (Variance Inflation Factor). Suatu model regresi menunjukkan adanya multikolonearitas jika:

1. Tingkat korelasi $>0,05 \%$,

2. Nilai Tolerance $<0,10$, atau

3. NilaiVIF $>10$.

Model regresi yang baik seharusnya tidak terajdi korelasi atau tidak terjadi multikolinearitas antar variabel independen (Ghozali, 2007). 
Uji heteroskedastisitas bertujuan untuk menguji apakah dalam model regesi terjadi ketidaksamaan varians dari residual satu pengamatan ke pengamatan yang lain. Jika varians dari residual satu pengamatan ke pengamatan lain tetap, maka disebut homoskedastisitas dan jika berbeda disebut heteroskedastisitas. Untuk menguji apakah tidak terjadi heterokedastisitas digunakan uji satistik Glejser SPSS, jika signifikansi lebih besar dari 0.05 maka dapat disimpulkan bahwa tidak terjadi heterokedastisitas (Ghozali 2007).

Uji autokorelasi bertujuan untuk mengetahui apakah dalam suatu model regresi linear terdapat korelasi antara penggangu pada periode $t$ dengan kesalahan pada periode t-1 (sebelumnya). Autokorelasi muncul akibat observasi yang berurutan sepanjang waktu berkaitan satu sama lain. Masalah ini timbul karena residual tidak bebas dari satu observasi ke observasi lainya, model regresi yang baik adalah yang bebas autokorelasi (Ghozali, 2011).

Alat analisis yang digunakan adalah uji Run Test. Run Test sebagai bagian dari statistik nonparametik dapat digunakan menguji apakah antar residual terdapat korelasi yang tinggi atau tidak. Jika antara residual terdapat hubungan korelasi maka dikatakan bahwa residual adalah acak atau random. Run Test digunakan untuk melihat apakah residual terjadi secara acak atau tidak.

Pengambilan keputusan pada uji Run Test adalah sebagai berikut:

1. Jika hasil uji Run Test menunjukan nilai signifikan lebih kecil dari 0,05 maka dapat disimpulkan bahwa residual tidak random atau terjadi autokorelasi antar nilai residual.

2. Jika hasil uji Run Test menunjukan nilai signifikan lebih besar dari 0,05 dapat disimpulkan bahwa residual random atau tidak autokorelasi antar nilai residual.

Regresi berganda digunakan untuk menguji apakah variabel-variabel independen personal background (X1), political background (X2), pengetahuan anggota DPRD tentang anggaran (X3), mempengaruhi peran anggota DPRD dalam pengawasan keuangan daerah APBD (Y). Model regresi berganda yang digunakan untuk menguji hipotesis sebagai berikut:

$$
\mathbf{Y}=\mathbf{a}+\mathbf{b}_{1} \mathbf{X}_{1}+\mathbf{b}_{2} \mathbf{X}_{2}+\mathbf{b}_{3} \mathbf{X}_{3}+\mathbf{e}
$$

Keterangan

$\mathrm{Y}=$ Pengawasan Keuangan Daerah (APBD)

$\mathrm{a}=$ Konstanta

$\mathrm{X} 1$ = Personal Background
$\mathrm{X} 2=$ Political Background

$\mathrm{X} 3$ = Pengetahuan Anggota DPRD tentang Anggaran

$b_{i}=$ Koefisien Regresi

$\mathrm{e}=$ error

\section{HASIL DAN PEMBAHASAN}

\section{Analisis Deskriptif Variabel}

Data penelitian ini dikumpulkan dengan menyebarkan 49 kuesioner secara langsung kepada responden yang mana responden tersebut yaitu: Anggota DPRD Provinsi Papua Barat periode 2014-2019. Dari 49 kuesioner yang disebarkan, 43 kuesioner atau 87,76\% yang diterima kembali dan 6 kuesioner tidak kembali atau $12,24 \%$. Dengan demikian, tingkat pengembalian yang diperoleh adalah $87,76 \%$. Jumlah anggota dewan perkabupaten dapat dijabarkan sebagai berikut: Kabupaten Sorong berjumlah 7 orang, Kota Sorong berjumlah 12, Kabupaten Manokwari berjumlah 7 orang. Kabupaten Arfak bejumlah 4 orang, Kabupaten Manokwari selatan 3 orang, Kabupaten Raja Ampat berjumlah 3 orang, Kabupaten Sorong Selatan berjumlah 2 orang, Kabupaten Maybrat berjumlah 4 orang, Kabupaten Kaimana berjumlah 4 orang, Kabupaten Teluk Bintuni berjumlah 5 orang, Kabupaten Teluk Wondama berjumlah 2 orang, Kabupaten Fak-Fak berjumlah 2 orang, Kabupaten Tambrauw berjumlah 1 orang. Jadi jumlah keseluruhan anggota DPRD Provinsi Papua Barat adalah sebanyak 56 orang. Gambar 1 menyajikan ringkasan jumlah anggota DPRD Provinsi Papua Barat.

Uji statistik deskriptif digunakan untuk mendeskripsikan variabel-variabel dalam penelitian ini. Alat analisis yang digunakan adalah rata-rata (mean), standar deviasi, maksimum, dan minimum (Ghozali, 2007). Hasil uji statistik deskriptif dapat dilihat pada Tabel 1.

Variabel personal background memiliki nilai tertiggi yaitu nilai minimum sebesar 42 dan nilai maximum sebesar 57 dengan rata-rata nilai mean sebesar 48.744, nilai deviasi standar sebesar 3.0323 dan variancenya sebesar 9.195. sedangkan variabel pengetahuan dewan tentang anggaran memiliki nilai terenda yaitu nilai manimum sebesar 27 dan nilai maksimum sebesar 55 dengan nilai rata-rata mean sebesar 48.744, nilai deviasi standar sebesar 3.9151 dan variancenya sebesar 15.328 . 


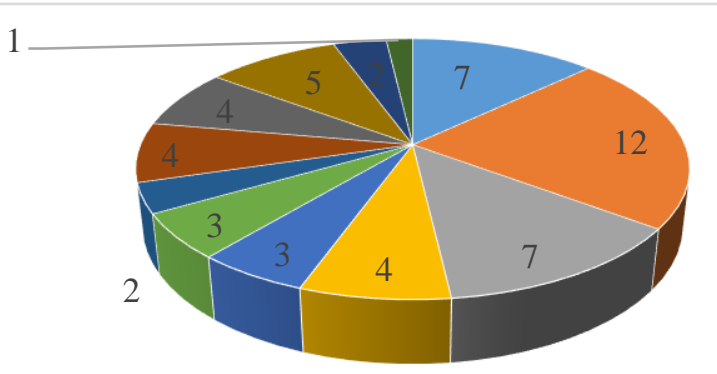

- Kabupaten Sorong

- Kabupaten Arfak

- Kabupaten Sorong Selatan

- Kabupaten Teluk Bintuni
- Kota Sorong

- Kabupaten Manokwari selatan

- Kabupaten Maybrat

- Kabupaten Fak-Fak
- Kabupaten Manokwari

- Kabupaten Raja Ampat

- Kabupaten Kaimana

- Kabupaten Tambrauw

Sumber: Sekretariat DPRD Prov.Papua Barat

Gambar 1. Jumlah Anggota DPRD Papua Barat

Tabel 1. Hasil Uji Analisis Statistik Deskriptif

\begin{tabular}{ccccccc}
\hline Variabel & $N$ & Minimum & Maximum & Mean & Std. Deviation & Variance \\
\hline$X_{1}$ & 43 & 42.0 & 57.0 & 48.744 & 3.0323 & 9.195 \\
$X_{2}$ & 43 & 38.0 & 55.0 & 46.651 & 3.6767 & 13.518 \\
$X_{3}$ & 43 & 27.0 & 43.0 & 36.651 & 3.9151 & 15.328 \\
$Y$ & 43 & 29.0 & 45.0 & 38.116 & 3.4655 & 12.010 \\
Valid N (listwise) & 43 & & & & &
\end{tabular}

Sumber: Data diolah (2018)

Tabel 2. Hasil Uji Normalitas

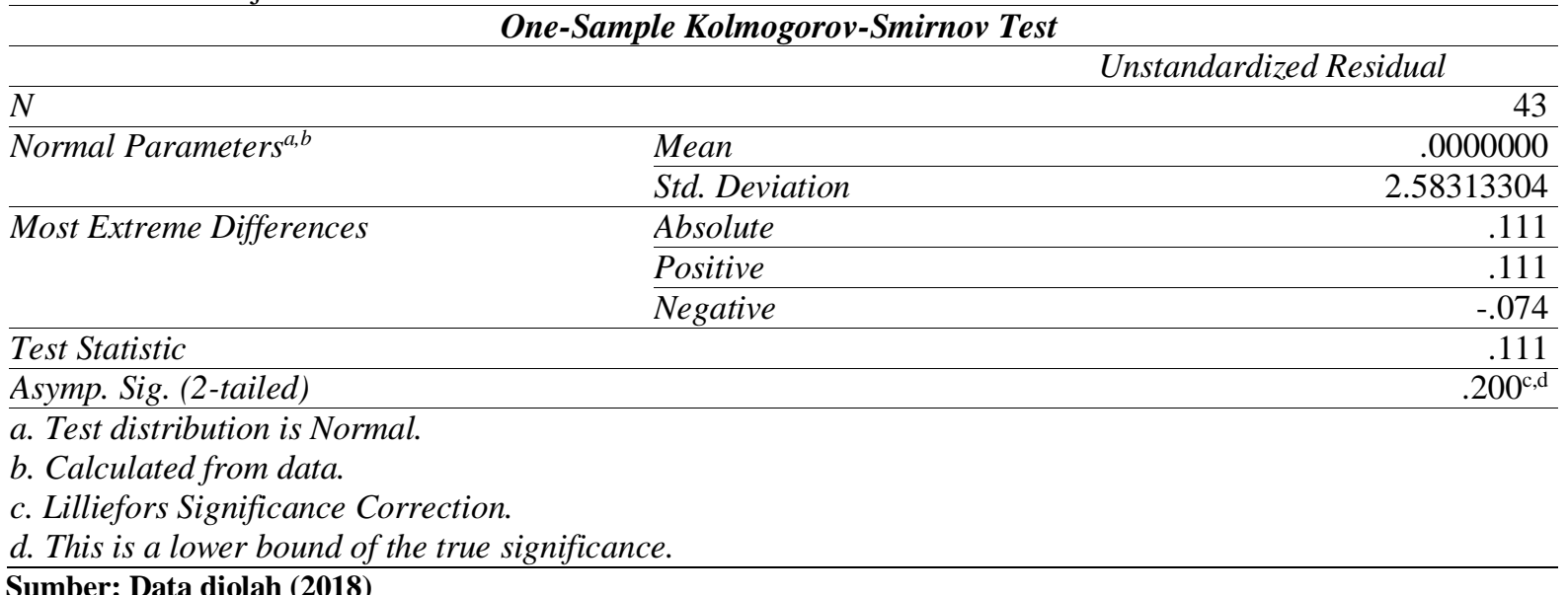

\section{Sumber: Data diolah (2018)}

Uji normalitas dilakukan untuk mengetahui apakah dalam model regresi, variabel-variabel memiliki data berdistribusi normal. Data yang berdistribusi normal akan memperkecil kemungkinan terjadinya bias. Untuk menguji apakah data berdistribusi normal atau tidak dilakukan uji statistik Kolmogorov Smirnov Test. Hasil uji normalitas dapat dilihat pada Tabel 2. Berdasarkan Tabel 2, nilai kolmogrov-smirnov test adalah 0,111 dan nilai pada signifikansi sebesar 0,200 lebih besar dari 0,05 maka dapat dikatakan bahwa data tersebut berdistribusi normal.

Uji multikolinearitas bertujuan untuk menguji apakah regresi ditemukan adanya korelasi antara variabel independen, maka uji jenis ini hanya diperuntukan untuk penelitian yang memiliki variabel independen lebih dari satu. Uji multikolinearitas dapat dilakukan dengan dua cara yaitu melihat VIF ( Variance Inflation Factors) dan nilai tolerance. Jika VIF $>10$ dan nilai torelance $<0.10$ maka tidak terjadi gejala multikolinearitas (Ghozali, 2007) (Tabel 3)

Selain dengan melihat VIF, data bebas dari gejala multikolinearitas dapat dilihat dengan menunjukan bahwa variabel independen memiliki nilai toleransi $>0.05$, maka dapat dijelaskan bahwa tidak terdapat multikolinearitas antara variabel indenpenden dalam model regresi. 
Tabel 3. Hasil Uji Multikolinearitas

\begin{tabular}{ccc} 
Model & \multicolumn{2}{c}{ Coleniarity Statistic } \\
\cline { 2 - 3 } Personal Background & Tolerance & 1.231 \\
Political Background & 0.813 & 1.274 \\
Pengetahuan dewan tentang anggaran & 0.785 & 1.164 \\
\hline
\end{tabular}

Sumber: Data diolah (2018)

Tabel 4. Hasil Uji Heterokedastisitas

\begin{tabular}{lcc}
\hline \multicolumn{1}{c}{ Variabel } & Signifikan & Keterangan \\
\hline Personal Background & 0.092 & Homokedastisitas \\
Political Background & 0.112 & Homokedastisitas \\
Pengetahuan dewan tentang anggaran & 0.646 & Homokedastisitas \\
\hline
\end{tabular}

Sumber: Data diolah (2018)

Uji heterokedastisitas bertujuan untuk menguji apakah dalam model regresi terjadi ketidaksamaan varians dari residual atau pengamatan ke pengamatan yang lain. Untuk menguji apakah tidak terjadi heterokedastisitas digunakan uji statistik Glejser SPSS, jika signifikansi lebih besar dari 0.05 maka dapat disimpulkan bahwa tidak terjadi heterokedastisitas (Ghozali, 2007). Hasil uji heterokedastisitas dapat dilihat pada tabel 4 . Nilai signifikan personal background sebesar 0.092 , political background sebesar 0.112, pengetahuan dewan tentang anggaran sebesar 0.646, maka ketiga variabel tersebut menjelaskan bahwa tidak terjadi heterokedastisitas karna nilai signifikannya > 0.05 .

Uji autokorelasi bertujuan untuk mengetahui apakah dalam suatu model regresi linear terdapat korelasi antara penggangu pada periode $t$ dengan kesalahan pada periode $\mathrm{t}$ (sebelumnya). Alat analisis yang digunakan adalah uji Run Test sebagai bagian dari statistik non-parametik yang digunakan untuk menguji apakah antar residual terdapat korelasi yang tinggi atau tidak. Hasil uji Test Run menunjukan nilai signifikan apabila nilai lebih besar dari 0,05 maka dapat disimpulkan bahwa residual tidak terjadi autokorelasi. Hasil autokorelasi dapat dilihat pada Tabel 5.

Tabel 5. Hasil Uji Autokorelasi

\begin{tabular}{lc}
\hline & Unstandardized Residual \\
\hline Test Value & -.22723 \\
Cases $<$ Test Value & 21 \\
Cases $>=$ Test Value & 22 \\
Total Cases & 43 \\
Number of Runs & 25 \\
Z & .621 \\
Asymp. Sig. $(2$-tailed) & .534 \\
\hline
\end{tabular}

Sumber: Data diolah (2018)

Tabel 6. Hasil Uji Analisis Regresi Berganda

\begin{tabular}{|c|c|c|c|c|c|}
\hline \multirow{2}{*}{ Model } & \multicolumn{2}{|c|}{ Unstandardized Coefficients } & \multirow{2}{*}{$\frac{\text { Standardized Coefficients }}{\text { Beta }}$} & \multirow{2}{*}{$T$} & \multirow{2}{*}{ Sig. } \\
\hline & $B$ & Std. Error & & & \\
\hline 1 (Constant) & 4.540 & 7.363 & & .617 & .541 \\
\hline$X_{1}$ & .332 & .151 & .291 & 2.195 & .034 \\
\hline$X_{2}$ & .015 & .127 & .016 & .117 & .907 \\
\hline$X_{3}$ & .455 & .114 & .514 & 3.995 & .000 \\
\hline
\end{tabular}

Sumber: Data diolah (2018)

Hasil uji autokorelasi menggunakan uji Run Test memiliki nilai signifikan sebesar 0.534 lebih besar dari 0.05 maka dapat disimpulkan bahwa model regresi tidak terdapat gejala autokorelasi. Regresi berganda digunakan untuk menguji apakah variabel-variabel independen personal background $\left(\mathrm{X}_{1}\right)$, political background $\left(\mathrm{X}_{2}\right)$, pengetahuan dewan tentang anggaran (X3) mempengaruhi peran DPRD dalam pengawasan keuangan daerah APBD (Y). Hasil uji regresi berganda dapat dilihat pada Tabel 6, dengan persamaan regresi sebagai berikut:

$$
\mathrm{Y}=4.540-0.332 \times 1+0.015 \times 2+0.455 \times 3+e
$$

Bentuk persamaan diatas memberikan gambaran regresi sebagai berikut: 
1. Konstanta sebesar 4.540 menyatakan bahwa variabel bebas dianggap konstanta, maka pengawasan keuangan daerah diDPRD Provinsi Papua Barat adalah 4.540.

2. Personal Background mempunyai nilai koefisien regresi sebesar -0.332 , yang berarti apabila terjadi peningkatan variabel personal background maka pengawasan keuangan daerah diDPRD Provinsi Papua Barat berkurang sebesar 0.332 .

3. Political Political mempunyai nilai koefisien regresi sebesar 0.015 , yang berarti apabila terjadi peningkatan variabel political background maka pengawasan keuangan daerah diDPRD Provinsi Papua Barat bertambah sebesar 0.015 .

4. Pengetahuan dewan tentang anggaran mempunyai nilai koefisien regresi sebesar 0.455 , yang berarti apabila terjadi peningkatan variabel pengetahuan dewan tentang anggaran maka pengawasan keuangan daerah diDPRD Provinsi Papua Barat bertambah sebesar 0.455.

Uji model pada dasarnya menunjukan apakah variabel independen atau variabel bebas yang dimasukan dalam model mempunyai pengaruh bersama-sama terhadap variabel dependen atau variabel terikat (Ghozali, 2012). Hasil uji F dapat dilihat pada Tabel 7.

Tabel 7. Hasil Uji F

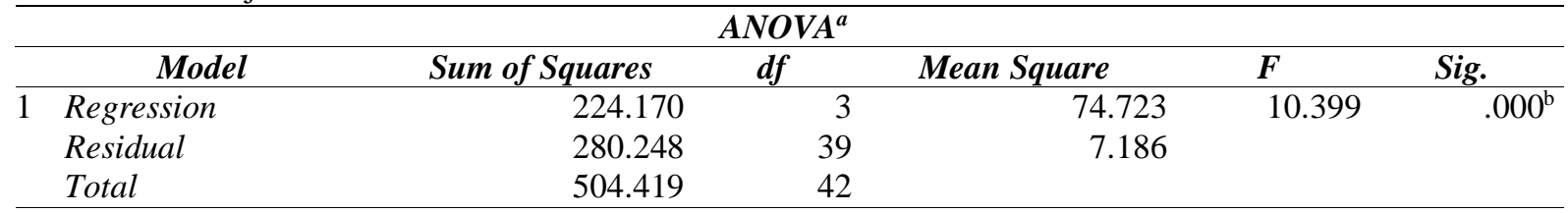

Sumber: Data diolah (2018)

Tabel 8. Hasil Uji Parsial (Uji $t$ )

\begin{tabular}{|c|c|c|c|c|c|c|}
\hline \multirow{2}{*}{\multicolumn{2}{|c|}{ Model }} & \multicolumn{2}{|c|}{ Unstandardized Coefficients } & \multirow{2}{*}{$\frac{\text { Standardized Coefficients }}{\text { Beta }}$} & \multirow{2}{*}{$\mathbf{t}$} & \multirow{2}{*}{ Sig. } \\
\hline & & B & Std. Error & & & \\
\hline 1 & (Constant) & 4.540 & 7.363 & & .617 & .541 \\
\hline & $\mathrm{X} 1$ & .332 & 151 & 291 & 2.195 & .034 \\
\hline & $\mathrm{X} 2$ & .015 & .127 & .016 & .117 & .907 \\
\hline & $\mathrm{X} 3$ & .455 & .114 & .514 & 3.995 & .000 \\
\hline
\end{tabular}

Sumber: Data diolah (2018)

Tabel 9. Hasil Uji Koefisien Determinan $\left(\mathrm{R}^{2}\right)$

\begin{tabular}{ccccc}
\hline \multicolumn{5}{c}{ Model Summary $^{b}$} \\
\hline Model & $R$ & $R$ Square & Adjusted $R$ Square & Std. Error of the Estimate \\
\hline 1 & $.667^{\mathrm{a}}$ & .444 & .402 & 2.6806 \\
\hline
\end{tabular}

a. Predictors: (Constant), X3, X1, X2, b. Dependent Variable: $Y$

Sumber: Data diolah (2018)

Berdasarkan Tabel 8, diperoleh hasil pengujian hipotesis secara parsial untuk setiap variabel independen sebagai berikut:

1. Variabel personal background mempunyai $\mathrm{t}$ hitung 2.195 dengan nilai signifikansi sebesar 0.034 , oleh karena nilai signifikansi lebih kecil dari 0.05 , sehingga dapat dikatakan bahwa variabel personal background berpengaruh positif terhadap pengawasan keuangan daerah diDPRD Provinsi Papua Barat. Sehingga dapat dikatakan hipotesis pertama diterima.

2. Variabel political background mempunyai thitung 0.117 dengan nilai signifikansi sebesar 0.907 , oleh karena nilai signifikansi lebih besar dari 0.05 , sehingga dapat dikatakan bahwa variabel political background secara parsial tidak berpengaruh terhadap pengawasan keuangan daerah diDPRD Provinsi Papua Barat. Sehingga dapat dikatakan hipotesis kedua ditolak.

3. Variabel pengetahuan dewan tentang anggaran mempunyai $t$ hitung 3.995 dengan nilai signifikansi sebesar 0.000 , oleh karena nilai signifikansi lebih kecil dari 0.05 , sehingga dapat dikatakan bahwa variabel pengetahuan dewan tentang anggaranberpengaruh positif terhadap pengawasan keuangan daerah di DPRD Provinsi Papua Barat. Sehingga dapat dikatakan hipotesis ketiga diterima.

Koefesien Determinan $\left(\mathrm{R}^{2}\right)$ pada intinya mengukur seberapa jauh kemampuan sebuah model menerangkan variansi variabel dependen. Nilai $R^{2}$ adalah antara 0 dan 1 . 
Nilai $\mathrm{R}^{2}$ yang kecil berarti kemampuan variabelvariabel independen dalam menjelaskan variabel dependen sangat terbatas. Nilai mendekati 1 berarti variabel-variabel independen memberikan hampir semua informasi yang dibutuhkan untuk memprediksi variansi dependen (Ghozali, 2007).

Tabel 9 menunjukan bahwa adjusted $R$ Square sebesar 0.402 yang artinya sebesar 40,2\% variabel dependen yaitu pengawasan keuangan daerah diDPRD Provinsi Papua Barat dapat dijelaskan oleh variabel independennya yaitu personal background, political background dan pengetahuan dewan tentang anggaran. Sedangkan sisanya $59.8 \%$ dijelaskan oleh variabel lain diluar penelitian ini atau tidak dimasukan dalam model.

\section{Pengaruh Personal Background Terhadap Peran DPRD Dalam Pengawasan Keuangan Daerah.}

Hasil penelitian menunjukan bahwa personal background secara signifikan berpengaruh terhadap peran DPRD dalam pengawasan keuangan daerah. Hal ini dibuktikan dengan uji statistik uji t dapat dilihat pada tabel 8 dimana variabel personal background memiliki t hitung 2.195 dengan nilai signifikansi 0.034 , dalam ini nilai signifikansi dari variabel personal background sebesar $0.034<0.05$. Sehingga dapat dikatakan bahwa variabel personal background secara signifikan berpengaruh terhadap peran DPRD dalam pengawasan keuangan daerah. Dengan demikian, dapat dikatakan bahwa semakin baik personal background anggota DPRD maka akan semakin baik juga fungsi pengawasan keuangan. Hal ini juga dipengaruhi karena sebagian besar responden berasal dari tingkat pendidikan S1 (Sarjana) yaitu sebanyak 20 orang, S2 (Master) sebanyak 10 orang, dan S3 (Doktor) sebanyak 3 orang.

Hasil penelitian ini sejalan dengan penelitian Nisa (2016) yang menyatakan bahwa personal background berpengaruh terhadap peran DPRD dalam pengawasan keuanan dareah. Penelitian ini tidak konsisten dengan penelitian yang dilakukan oleh Amelia (2013), Kartika (2012) dan Dewi (2011), yang menyatakan bahwa personal background tidak berpengaruh terhadap peran DPRD dalam pengawasan keuangan daerah.

\section{Pengaruh Political Background Terhadap Peran DPRD Dalam Pengawasan Keuangan Daerah}

Hasil penelitian menunjukan bahwa Political Background secara signifikan tidak berpengaruh terhadap peran DPRD dalam pengawasan keuangan daerah. Hal ini dibuktikan dengan uji statistik uji t dapat dilihat pada tabel 8 dimana variabel personal background memiliki t hitung 0.117 dengan nilai signifikansi 0.907 , dalam ini nilai signifikansi dari variabel political background sebesar $0.0907>0.05$.hal ini di disebabkan karena sebagian besar anggota DPRD yang menjadi sampel memiliki political background yaitu terlihat dari pengalaman di politik, pengalaman di DPRD dan jabatan di partai politik. Hal ini juga dipengaruhi karena sebagian besar responden memiliki masa kerja di DPRD kurang dari 10 Tahun.

Hasil penelitian ini sejalan dengan penelitian Dewi (2011) yang menyatakan bahwa political background tidak berpengaruh terhadap peran DPRD dalam pengawasan keuangan dareah. Penelitian ini tidak konsisten dengan penelitian yang dilakukan oleh Nisa (2016), dan Amelia (2011), yang menyatakan bahwa political background berpengaruh terhadap peran DPRD dalam pengawasan keuangan daerah.

\section{Pengaruh Pengetahuan Dewan Tentang Anggaran Teradap Peran DPRD Dalam Pengawasan Keuangan Daerah}

Hasil penelitian menunjukan bahwa pengetahuan dewan tentang anggaran secara signifikan berpengaruh terhadap peran DPRD dalam pengawasan keuangan daerah. Hal ini dibuktikan dengan uji statistik uji t dapat dilihat pada tabel 8 dimana variabel pengetahuan dewan tentang anggaran memiliki t hitung 3.995 dengan nilai signifikansi 0.000 , dalam ini nilai signifikansi dari variabel pengetahuan dewan tentang anggaran sebesar $0.000<0.05$. Sehingga dapat dikatakan bahwa variabel pengetahuan dewan tentang anggaran secara signifikan berpengaruh terhadap peran DPRD dalam pengawasan keuangan daerah. Hal ini menunjukan anggota dewan mengetahui keseluruan mekanisme penyusunan anggaran mulai dari tahap perencanaan sampai tahap pertangggungjawaban serta anggota dewan mengetahui tentang peraturan perundang-undangan yang mengatur pengelolaan keuangan daerah APBD.

Hasil penelitian ini sejalan dengan penelitian Amelia (2013), dan Kartika (2012) yang menyatakan bahwa pengetahuan dewan tentang anggaran berpengaruh terhadap peran DPRD dalam pengawasan keuangan dareah. Penelitian ini tidak konsisten dengan penelitian yang 
dilakukan oleh Nisa (2016), dan Dewi (2011), yang menyatakan bahwa personal background tidak berpengaruh terhadap peran DPRD dalam pengawasan keuangan daerah.

\section{KESIMPULAN}

Penelitian ini bertujuan untuk mengetahui pengaruh Personal Background, Political Background dan pengetahuan dewan tentang anggaran terhadap peran DPRD dalam pengawasan keuangan daerah. Berdasarkan hasil penelitian yang dilakukan, maka dapat diambil kesimpulan sebagai berikut:

1. Secara parsial atau individual Personal Background secara signifikan berpengaruh terhadap peran DPRD dalam pengawasan keuangan daerah, hal ini menunjukan bahwa semakin anggota DPRD memiliki Personal Background yang tinggi maka pengawasan keuangan daerah yang dilakukan juga semakin maksimal.

2. Secara parsial atau individual Political Background secara signifikan tidak berpengaruh terhadap peran DPRD dalam pengawasan keuangan daerah, dikarena political Background tidak selalu menjadi tolak ukur dan tidak sepenuhnya mempengaruhi peran DPRD dalam pengawasan keuangan.

3. Secara parsial atau individual pengetahuan dewan tentang anggaran secara signifikan berpengaruh terhadap peran DPRD dalam pengawasan keuangan daerah, hal ini menunjukan bahwa anggota dewan mengetahui keseluruhan mekanisme penyusunan anggaran mulai dari tahap perencanaan sampai pada tahap pertanggungjawaban serata anggota dewan mengetahui tentang peraturan perundangundangan yang mengatur pengelolaan keuangan daerah APBD.

DPRD diharapkan memiliki pengetahuan yang memadai sehingga dapat mengambil keputusan dengan baik. Pengetahuan sangat terkait dengan pendidikan, pelatihan, dan pengalaman. Sehingga, dapat meningkatkan kinerja. Penelitian selanjutnya diharapkan mempertimbangkan variabel lain yang mungkin dapat mempengaruhi pengawasan keuangan daerah.

\section{DAFTAR PUSTAKA}

Amelia, Nurul Fitri. (2013). Faktor-Faktor yang mempengaruhi Peran DPRD dalam Pengawasan Keuangan Daerah. Universitas Negeri Semarang.

Nisa, Choyrun. (2016). Pengaruh personal background dan Pengetahuan Dewan tentang Anggaran terhadap Pengawasan Keuangan Daerah (APBD). Universitas Jember.

Ghozali, Imam. (2007). Aplikasi analisis Multivariate dengan Program SPSS. Semarang: badan penerbit universitas Dionerogo.

Ghozali, Iman. (2012). Aplikasi Analisis Multivariate dengan Program SPSS. Semarang. badan penerbit universitas Diponerogo.

Kartikasari, Dewi. (2012). Pengaruh Personal Background, Political Background, Pemahaman Regulasi Terhadap Peran Anggota DPRD Dalam Pengawasan Keuangan Daerah (Studi Kasus pada DPRD Kabupaten Boyolali) Accounting Analisis Jounal. Semarang: Universitas Negeri Semarang.

Republik Indonesia, (2004). Undang-Undang Nomor 33 Tahun 2004 tentang Perimbangan Keuangan antara Pusat dan Daerah.

Republik Indonesia, (2005). Peraturan Pemerintah Nomor 58 Tahun 2005 tentang Pengelolaan Keuangan Daerah.

Sugiyono. (2012). Metodologi Penelitian Akuntansi. Cetakan pertama: FE Nommensen Medan

Sugiyono. (2011). Metodologi Penelitian Bisnis. Bandung. Alfabeta.

Winarna, Jaka dan Murni. (2007). Pengaruh Personal Background, Pengaruh Politic Background, dan Pengetahuan Dewan tentang Anggaran terhadap Peranan DPRD dalam Pengawasan Keuangan Daerah. Surakarta. 